\title{
On The History of Formation and Ways of Penetration of the Relict Dendroflora into Chechnya and Adjacent Territories
}

\author{
Taysumov M.A. \\ Department of Biological Studies \\ Kh. Ibragimov Complex Institute of the \\ Russian Academy of Science \\ Grozny, Russia \\ musa_taisumov@mail.ru \\ Umaeva A.M. \\ Faculty of Biology \\ The Chechen State University \\ Grozny, Russia \\ 0892179@mail.ru \\ Abdurzakova A.S. \\ Faculty of Natural Science \\ Chechen State Pedagogical Institute \\ Grozny, Russia \\ anna-grozny@mail.ru

\section{Israilova S.A.} \\ Faculty of Natural Science \\ Chechen State Pedagogical Institute \\ Grozny, Russia \\ s.israilova@yandex.ru
}

\author{
Astamirova M.A.-M. \\ Faculty of Natural Science \\ Chechen State Pedagogical Institute \\ Grozny, Russia \\ astamirova@bk.ru
}

\author{
Shahgireeva Z.I. \\ Faculty of Biology \\ The Chechen State University \\ Grozny, Russia \\ 0892179@mail.ru
}

\author{
Magomadova R.S. \\ Faculty of Natural Science \\ The Chechen State Pedagogical Institute \\ Grozny, Russia \\ r.s.magomadova@mail.ru
}

\author{
Umarov R.M. \\ Department of Biological and Medical Studies \\ The Academy of Sciences of the Chechen Republic \\ Grozny, Russia \\ umrusmuh@mail.ru
}

The eroded mountain slopes after the glaciers retreat were also characterized by the successions of small willow and willowbirch crook-stem forests and long-aged birch and pine forests with the developed mossy-suffruticose or grass cover. Besides, the other issues of succession relationships and phytocenotic evolution during the Holocene of the main forest formations of the North Caucasus were researched.

The history of the forest vegetation formation in the North Caucasus during the ice age was studied on the basis of the study of succession processes, data of the spore-and-pollen analysis, pollen diagrams, peatlands, fossil plant residues of the Holocene and earlier sediments in the different territories of the North Caucasus, as well as indirect methods of analyzing the floristic composition, genetic relationships and geographical distribution of individual phytocenoses components.

In the North-Western Caucasus during the whole period of the glacial age there were dark-coniferous and deciduous forests fringing the trough valleys freeing themselves from ice. In the Central Caucasus the dark-coniferous forests are replaced by deciduous ones that can be met in the inner parts of mountain 
systems. In the forests of Nagorny Dagestan in the majority of closed and orographically isolated valleys the pine and birch formations still dominate.

\section{Keywords-forest history, North Caucasus, dendroflora}

\section{INTRODUCTION}

In the Chechen Republic and the adjacent territories the floral studies were carried out by botanists; they included the studies of relics, that is, the endangered species to be protected [1-7]. A lot of information about the composition of the relic dendroflora of this territory was collected; its botanical and geographical analysis was performed. However, there are no detailed data about the history of its formation.
A detailed research and comprehensive analysis of relics will help to understand the ways of relics penetration, the history of the formation of the flora and the vegetation cover of the studied territory. A.A. Grossheim [8] paid great attention to the analysis of flora using natural botanical groups. He wrote: "The areas reflect the historical course of the species' development and, therefore, floristic groups created on the basis of habitats analysis are at the same time genetic groups of the given flora reflecting historical development and composition" (p. 36.).

In the natural flora of Chechnya and the adjacent territory 179 trees and shrubs grow [6]. According to the system of geographical types of habitats developed by A.A. Grossheim [9] for the Caucasus, there are 273 species of natural dendroflora (Table 1).

TABLE I. GegraphicAl ElEMENTS OF THE DENDROFlora of THE CAUCASUs (By A.A. GrossheIM)

\begin{tabular}{|c|c|c|c|c|c|c|c|}
\hline \multirow{2}{*}{ Habitats Types } & \multicolumn{7}{|c|}{ Bioforms } \\
\hline & Trees & Shrubs & Subshrubs & Dwarf shrubs & Low dwarf shrubs & Lianas & Total \\
\hline Ancient & 6 & 5 & 0 & 1 & 1 & 3 & 16 \\
\hline Boreal & 32 & 32 & 6 & 6 & 1 & 1 & 78 \\
\hline \multicolumn{8}{|c|}{ Siccocolous } \\
\hline Anterior Asian & 6 & 19 & 7 & 1 & 2 & 0 & 35 \\
\hline Middle Asian & 8 & 20 & 14 & 3 & 2 & 1 & 48 \\
\hline Central Asian & 0 & 5 & 1 & 0 & 0 & 0 & 6 \\
\hline Caucasian & 15 & 24 & 7 & 8 & 6 & 3 & 63 \\
\hline Steppe & 1 & 7 & 4 & 2 & 2 & 0 & 16 \\
\hline Desert & 1 & 3 & 3 & 3 & 1 & 0 & 11 \\
\hline Total & 69 & 115 & 42 & 24 & 15 & 8 & 273 \\
\hline
\end{tabular}

\section{MEthods AND MATERIALS}

To characterize the flora botanically and geographically, the determination of the percentage ratio of its species composition belonging to the certain types of habitats is of the greatest importance. As Table 1 shows the role of siccocolous $(32.5 \%)$ and boreal $(28.5 \%)$ types of habitat in the composition of natural dendroflora is large; among the species with the boreal type of habitat trees and shrubs predominate, whereas the siccocolous type of area is mainly represented by subshrubs and dwarf shrubs that are concentrated chiefly in the mountainous part of the researched area. The main core of the boreal type is represented by European and Palearctic species. The siccocolous type is represented by the Mediterranean (17.5\%) and Anterior-Asian species.

The Caucasian species account for $23 \%$. The ancient type of the habitat includes 16 species $(5.8 \%)$.

In addition to the relics of the ancient type of habitat, there are tertiary, glacial, xerothermic relics of the boreal, siccocolous, Caucasian steppe types of habitat in Chechnya and adjacent territories.

Tertiary relics are the most ancient representatives of the Caucasian flora. The criterion of a species' antiquity is the confirmation of its age by the fossil remains. Unfortunately, there are no literature data about the fossil flora of the Chechen Republic, but they are found in the nearby territories of the Western Ciscaucasia, the regions of the towns of Krymsk [10-111] and Armavir [11,12]. The species include: Acer laetum C.A. Mey., Alnus glutinosa (L.) Gaertn., Allium ursinum L., Brunnera macrophylla (Adams) I.M. Johnst., Vaccinium arctostaphylos L., Quercus petrea L., Viburnum opulus L., Corylus avellana (L.) H. Karst., Caragana, grandiflora (M. Bieb.) DC., Colutea orientalis Mill., Cerasus avium (L.) Moench, Carpinus caucasica Gross. (Carpinus betulus L.), Cornus mas L., Juglans regia L., Juniperus oblonga M. Bieb., J. communis L., Sorbus torminalis (L.) Crantz, S. graeca (Spach) Lodd. ex Schauer, Vitis sylvestris C.C. Gmel., Eguisetum arvense L., Euonymus verricosa Scop., E. latifolia (L.) Mill., Ulmus scabra Mill., Lonicera caprifolia L., Populus tremula L., Pyrus caucasica Fed., Pyrus salicifolia Pall., Mespilus germanica L., Fagus orientalis Lipsky, Rhododenron caucasicum Pall., Rh. luteum Sweet, Tilia cordata Mill.,, Taxus baccata L., Tamus communis L., Hippophaë rhamnoides L., Hedera pastuchovii Woronow, Ulmus glabra Huds. To the tertiary (Pliocene) species in addition to these trees and shrubs the following types refer as well: Allium paradoxum (M. Bieb.) G. Don, Dentaria quinquefolia $M$. Bieb., Phyllitis scolopendrium (L.) Newman, Marsilea quadrifolia L., Salvinia natans (L.) All., Silene chlorifolia Smith, Ophioglossum vulgatum L., Asarum ibericum Stev., Betula raddeana, Nymphaea alba, Primula amoena, Primula woronowii, Helleborus caucasicus, Atropa caucasica, Papaver bracteatum, I tenuifolia, Pseudovesicaria digitata, Ornithogalum arcuatum, Cephalaria balkharica, Cephalaria dagestanica, Primula farinifolia, Rhamnus depressa, 
Vaccinium arctostaphylos, Asarum intermedium, Adoxa moschatellina, Gentiana schistocalyx [13-16].

There are quite many species that are the components of relict vegetation formations that survived not only in Chechnya but in the entire North Caucasus due to the appropriate climatic conditions there. In the flora of the Chechen Republic these species are represented by: Actaea spicata, Adoxa moschatellina, Amberboa glauca, Artemisia salsoloides, Asplenium ruta-muraria, Asplenium septemtrionale, Asplenium trichomanes, Campanula ossetica, Ceterach officinarum, Gadelia lactiflora, Gentiana grossheimii, Medicago daghestanica, Ophioglossum vulgatum, Omphalodes rupestris, Orthylia secunda, Onosma armeniaca, Polypodium vulgare, Phyllitis scolopendrium, Polystichum aculeatum, Polystichum braunii, Pseudoversicaria digitata, Pyrola rotundifolia, Psephellus prokhanovii, Rhaponticum pulchrum, Pachyphragma macrophyllum, Tephroseris subfloccosus, Equisetum hiemale, Helleborus caucasicus, Vavilovia formosa, Saxifraga ruprechtii. For these representatives the indicators of antiquity are: leaves that do not die off for the winter (greenness in winter), belonging to primitive families, and systematic isolation.

Glacial relics are survived representatives of the floras characteristic of the entire North Caucasus in glacial epochs. Some species are the remnants of cold and wet epochs of the Upper Pliocene. Among them two complexes can be identified: the boreal and the Caucasian ones.

The boreal complex is represented by the species whose main habitat is the temperate zone of Eurasia. The following species refer to the group of species with the main habitat in the temperate Eurasia, and with the isolated island or spotted distribution in the Caucasus: Salix caprea, Daphne mezereum, Dianthus arenarius, Linnaea borealis, Coccigante flos-cuculi, Ranunculus tebulossicus.

The second group of species, also a boreal one, in addition to the disjunctive habitat in the Eastern Caucasus, usually has more extensive areas of habitat in the Caucasus Mountains. They are the following species: Thelypteris palustris, Carex ponicea, Omphalodes scorpioides, Cotoneaster integerrima, Doronicum orientale, Hypopitis monotropa, etc.

The Caucasian complex is represented by the species with the main habitat in the mountainous part of the Caucasus, and the disjunctive part is located at the heights of Rocky Ridge: Dryopteris caucasica, Asperula caucasica, Anemonoides caucasica, Astragalus galegiformis, Scrophularia lateriflora, Amoria tumens, Solenanthus biebersteinii, Telekia speciosa.

Xerothermic relics (Cotinus coggygria, Capparis spinosa, Silene chlorifolia, Fumana procumdens, Euphorbia condilocarpa, Astragalus denudatus, Colutea orientalis, Medicago dagestanica, Papaver bracteatum, Cerasus incana, Celtis glabrata) are the remnants of floras characteristic of the Eastern Caucasus in the interglacial arid epochs. Some of them are characterized by the older (Upper Pliocene) age. They are classified into four complexes: Mediterranean, Pontian, Turanian and Caucasian.

The Mediterranean complex is represented by the species whose habitat is in the Crimean-Novorossiysk floristic province in the territory of the Caucasus: Alyssum obtusifolium, Crambe koktebelica, Sternbergia colchiciflora, Linum tauricum, Euphorbia petrophila, Iberis taurica, Scabiosa micrantha, Scabiosa rotata, Crocus speciosus.

The Pontian complex is formed by the species whose main habitat is to the north of the Kumo-Manych depression. Among them there are: Crambe pinnatifida, Alyssum rostratum, Medicago cancel lata, Calophaca wolgarica, Chamaecytisus borystenicus, Caragana mollis, Euphorbia tanaitica, Globularia punctata.

The Turanian complex is represented by a few species, the main habitat of which is located in the Pre-Caspian region and to the east of it. They are Fritillaria meleagroides, Ferula tatarica, Euphorbia praecox, Scabiosa isetensis.

The Caucasian complex is formed by the species of the Caucasian origin - Euphorbia glareosa, Thymus daghestanicus (the Eastern Caucasus), Vincetoxicum albivianum (Transcaucasia), Eremurus spectabilis (the Caucasus).

\section{RESULTS}

The list of relics of the dendroflora of Chechnya was compiled on the basis of the literary data $[4,6]$; it includes 31 species of trees, 23 shrubs, 6 lianas, 6 subshrubs, 6 dwarf shrubs, and 1 low dwarf shrub. They belong to 30 families and 48 genera. The majority of them belong to the following families: Rosaceae Juss. -12 species, Caprifoliaceae Juss. -6 species, Salicaceae Mirb. - 5 species, Betulaceae S.F. Gray 5 species, Aceraceae Juss, Corylaceae Mirb. - 4 species for each family.

The species with the boreal type of habitat prevail -25 species (32\%); among them there are 10 trees, 11 shrubs, 2 subshrubs and 2 dwarf shrubs. According to A.A. Grossheim [13], the northern species of Turgai flora began to penetrate into the territory of the Eastern Caucasus during the Tertiary period and ended in the Pliocene during the borealization of the Caucasian flora. The tertiary relics of Turgai flora are Populus tremula L. Prunus spinosa L., (P. stepposa Kotov.), Salix purpurea L., Sambucus nigra L., Taxus baccata L., Viburnum opulus L.).

The second migration of the northern species (Betula pendula Roth. $=$ B. verrucosa Ehrh., Vaccinum myrtillus L., Rhodococcum vitisidaea L., Linnea borealis L., Ramischia secunda (L.) Garcke = Orthilia secunda (L.) House.) took place in the glacial period.

These species grow in the piedmont and high-altitude parts in all beech, pine and birch forests of the Eastern Caucasus. The distribution of glacial relics, as it is noted by I..Z. Gusilashvilli [16], makes it possible to specify the boundaries of the ice sheet. In Chechnya the pine-oak forests survived on the dry stony slopes on the left bank of the Chanti-Argun beginning from the settlement of Zonakh to the ItumKalinsky basin; in places they mix with Betula pendula Roth ( $B$. verricosa Ehrh) in the species composition of which xerophytic species predominate [12]. Taking into account the fact that in the pine-oak forests there are glacial relics with the boreal habitat type along with siccocolous species, it is possible to assert their relict nature.

The second place in the variety of relict dendroflora is taken by the representatives with the siccocolous type of habitat. They include 19 species: 6 trees, 9 shrubs, 2 lianas, 1 subshrub, 1 dwarf shrub. A significant number of species with the siccocolous type of habitat indicates the ancient ties between the studied flora and the floras of Anterior Asia and the Mediterranean region that are located to the south. The prevailing species are of the Anterior-Asian origin (14\%): Quercus macranthera Fisch. et Mey., Quercus iberica Stev., Betula litwinowii Doluch., Daphne glomerata Lam., Cydonia oblonga Miller, Juniperus hemispherica J. et C.Presl. (J. depressa Stev.) 
$10.2 \%$ of species refer to the Mediterranean relics: Carpinus orientalis Mill., Viburnum lantana L., Clematis orientalis L., Lonicera caprifolium L., Cornus mas L., Cotinus coggygria Scop., Clematis orientalis L., Rhus coroaria L.

Within the researched territory the species with the siccocolous habitat type are mainly concentrated in the Terek-Kuma lowland and in arid basins.

The siccocolous flora is ancient. M.G. Popov [16] believed that even in the Tertiary period there were conditions for the siccocolous flora development in the southern Africa; then it spread throughout all desert places. The Anterior-Asian habitat type is a derivative of the mid-tertiary siccocolous flora. The Anterior-Asian species penetrated into the Eastern Caucasus in ancient times. Currently, the researched area is a secondary center of speciation of siccocolous species $[13,14]$. I.I. Tumadzhanov [18] believes that the expansion of mesophilic deciduous forests in this territory was preceded by dry phases, which contributed to the xerophytization of vegetation in the middle Pliocene, when the desert Iranian-Turanian flora elements expanded in the Eastern Caucasus successfully; their remnants survived in the form of relic enclaves in dry intemontane valleys. The Mediterranean species penetrated into the Caucasus at the end of the Pliocene and during the interglacial periods.

The species with the ancient type of habitat account for $20.5 \%$; among them there are 6 trees, 5 shrubs, 3 lianas, 1 dwarf shrub and 1 low dwarf shrub. They have heterogeneous origin. Some of them are the representatives of the ancient Eastern Mediterranean Tertiary flora (Fagus orientalis Lipsky, Rhododendron luteum Sweet, Mespilus germanica L., Periploca graeca L. and Smilax exelsa L.); the others are related to relics of the Colchian root (Acer trautvetteri Medw., Salix caucasica Anderss., Rhododendron caucasicum Pall., Thymus nummuralis Bieb. and Rubus caucasicus C.A. Mey.). The third group is represented by the relics of the Hirkan type-Acer laetum C.A. Mey., Alnus barbata C.A. Mey., Hedera pastuchovii Woronow.

The species of the Colchian type of habitat grow in the mountainous areas, whereas those of the Hirkan type are concentrated on lowlands and in river valleys.

Currently, a lot of types (Acer laetum C.A. Mey., Fagus orientalis Lipsky, Rhododendron luteum Sweet, Mespilus germanica L.) are quite common; and eastern beech form beech forests in the basins of the rivers Aksai, Assa, Sharo-Argun and Chanti-Argun as well as in the Vedensky, Nozhai-Yurtovsky and Shatoi regions.

There are a lot of relics in the river-valley of the Terek; a great deal of them (Cydonia oblonga Vill., Amygdalus nana L., Periploca graeca L., Cotinus coggygria Scop., etc.) grow at the boundary of their habitat, therefore, their population is shortening and they are to be protected.

The relics of the Caucasian type are represented mainly by trees: Quercus iberica Stev., Tilia caucasica Rupr., Pyrus salicifolia Pall., Pyrus caucasica Fed., Corylus colurna L., Pinus kochiana Klotzsch ex Koch (P. chamata (Stev.) Sosn., P. sosnowskyi Nakai), Betula raddeana Trautv., Juniperus oblonga Bieb.

In addition to the tertiary and glacial relics in this territory there are xerothermic relics, such as Ephedra distachya L., Kochia prostrata (L.) Schard., Helyanthemum nummulurium (L.) Dun.

On the basis of the given data, it can be concluded that within the borders of Chechnya and adjacent territories there are relics of different origin and territorial distribution growing in different altitudinal belts. The majority of the tertiary relics is concentrated in the floodplain forests of the Terek, Argun, Sunzha, Aksai, Hulhulau, Fortang, Assa, and others, where, in addition to the representatives of the dendroflora, there are also many herbaceous relics: Asparagus verticillata, Pteridium tauricum, Solenantus bibersteinii, Arum orientale, Allium paradoxum, Clininopodium vulgare, Asperula odorata, Cephalantera caucasica, Tamus communis, Hablitzia tamnoides, etc.

A huge number of tertiary relics among flowering and fern plants growing in beech forests belong to the ancient type. Most of them have boreal, siccocolous and Caucasian habitat types. In the highmountainous beech forests the relics of the glacial period predominate.

\section{CONCLUSION}

The wide expansion of the relics of the Holarctic boreal type in the beech forests of the North Caucasus confirms the view of I.I. Tumadzhanov, who notes that the expansion of beech forests is associated with the replacement of the previously dominant pine and birch forests [18-20]. At the same time a rather high percentage of species of the ancient habitat type and the boreal type relics of the arctotertiary root in beech forests makes it possible to state that the mesophilic broad-leaved forest vegetation survived during the ice age in isolated refugia.

Describing the replacement of the pine forests with the beech ones in the high-mountain belts, I.I. Tumadzhanov [18-20] notes that "in the lower belts in the eastern Caucasus the deciduous forests survived everywhere during the entire Pleistocene and served as centers of expansion in the era of interglacial warming during the Holocene".

While studying the history of the flora formation of the Eastern Caucasus, great attention should be paid to the relict juniper woodlands in the lower dry foothills and limestone of the Cretaceous period and to Juniperus polycarpus C. Koch. The following species can be also met there: Cerasus incana (Pall.) Spach., Spirea hypericifolia L., Cotihus coggygria Scop., Rhus cariaria L., Berberis vulgaris and Paliurus spina-christi Mill. - relics of the siccocolous type. The uplandxerophytic endemic plants predominate in the grass cover Tragacanta aurea, T. denudata, Thymus daghestanicus, Scutellaria oreophila, Hyssopus angustifolius.

The analysis of tree relics shows that the preglacial flora of the Eastern Caucasus was hylile mesophilic and siccocolous. The vegetation xerophytization occurred in the middle Pliocene, when the Eastern Caucasus was the centre of expansion of desert IranianTuranian floras.

Thus, in order to preserve the relics of the Eastern Caucasus, it is necessary to establish conservation areas and micro-reserves in the places of their maximum accumulation not only in the territory of Chechnya but also throughout the whole Eastern Caucasus. The study of the populations states that the mapping of relict, rare and endangered species will contribute to the effective implementation of the protection measures. 


\section{References}

[1] A.I. Galushko, Vegetation Cover of Chechen-Ingushetia, Grozny: Chechen-Ingush Publishing House, 1975, p. 118.

[2] A.A. Teymurov, M.A. Taysumov, "Invasion Traces of the Siccocolous Flora of Dagestan in Pyatigorye", South of Russia: Ecology of Development, no. 2, 2007, pp. 69-73.

[3] M.A. Taysumov, F.S. Omarkhadzhieva, Analysis of the Flora of the Chechen Republic, Grozny, 2012, p. 320.

[4] M.A. Taysumov, R.S. Magomadova, A.S. Abdurzakova, M.A.M. Astamirova, B.A. Khasuyeva, F.S. Omarkhadzhieva el al, "Analysis of Xerophyte Flora of the Russian Caucasus", Bulletin of KrasSAU, no. 6, 2014, pp. 124-132.

[5] M.U. Umarov, M.A. Taysumov, "Tertiary Relics of the Flora of the Chechen Republic", Bulletin of the Academy of Sciences of the Chechen Republic, vol. 23(2), 2014, pp 34-41.

[6] A.A. Grossheim, "Analysis of the Flora of the Caucasus", Proceedings of the Botanical Institute of Azerbaijan. FAN USSR, vol. 1, Baku, 1936, p. 260

[7] M.U. Umarov, M.A. Taysumov, "Dendroflora of the Chechen Republic: Latin, Russian and Chechen Names", Bulletin of the Chechen State University, no. 1, 2009, pp. 96-104

[8] A.I. Galushko, Flora of the North Caucasus, Rostov-on-Don: RSU, vol. 1, 1978, p.317; vol. 2, 1980, p. 350; vol. 3, 1980, p. 327.

[9] A.A Grossheim, Flora of the Caucasus - Baku, 1939-1967, vol. 1-4.

[10] A.A. Grossheim, The Vegetative Cover of the Caucasus, Moscow: Publishing House MOIP, 1948, p. 267.
[11] G.D. Pashkov, "Discoveries of New Plants of the Sarmatian Flora in the Western Ciscaucasia”, Botanical Journal, vol. 50, no. 8, 1965, pp. 10681077.

[12] G.D. Pashkov, "On the New Discovery of the Neogene Flora in the North Caucasus”, Botanical Journal, vol. 44, №no. 5, 1959, pp. 657-660.

[13] E.F. Kutuzkina, Sarmatian Flora of Armavi, synopsis of a thesis for a Candidate degree in biological sciences, Leningrad, 1962, p.16.

[14] A.L. Ivanov, Rare and Endangered Plants of Stavropol, Stavropol: Servis Shkola, 2002, p. 352

[15] A.I. Galushko, Main Refugia and Relics in the High-Mountain Flora of the Western Part of the Central Caucasus, Problems of Botany. Flora of Highlands and Its Development, Leningrad: Nauka, 1974.

[16] V.Z. Gusilashvilli, "On the Shelters of the Caucasian Tree Flora in the Glacial Period", Bulletin of Moscow Society of Nature Lovers, Department of Biology, vol. 79, no. 2, 1973, pp. 32-87.

[17] M.G. Popov, Pine Traits of History of the Flora Development of Central Asia, Tashkent, 1927.

[18] N.I. Kuznetsov, "Nagorny Dagestan and Significance of Development of the Flora of the Caucasus", Proceedings of the Russian Geographical Society, vol. 46, no. 6-7, 1910, pp. 210-220.

[19] I.I. Tumadzhanov, The Main Features of History and Geography of the Forest Vegetation of the Greater Caucasus in the Pleistocene and Holocene, Proceedings of the Academy of Sciences of the USSR, section: Geography, vol. 3, 1973,. p. 103.

[20] I.I. Tumadzhanov, "Beech and Beech Forests in Nagorny Dagestan", Proceedings of Tbilisi Botanical Institute, vol. 7, 1940. 